\title{
The Growth Implication of Trade Liberalization in West Africa
}

\author{
${ }^{1}$ Umoh, OkonJoseph (Ph. D. $)^{2}$ Onye, KennethUgwu \\ ${ }^{1}$ and ${ }^{2}$ Department of Economics, Faculty of Social Sciences, University of Uyo, Nigeria
}

\begin{abstract}
This study empirically investigates the growth implication of trade liberalization in twelve West African (WA) countries using time series data for the period of 1970-2011. Relying on a Vector error correction model (VECM), our result indicates that trade orientation (trade policy variable) investment rate and exports shocks have significant positive impact on growth in 8 out of 12 WA economies. This suggests that it is possible to stimulate economic growth in some African countries through an outward-looking strategy of export expansion. We, thus, conclude that WA economies can vigorously pursue trade liberalization in order to enhance their growth performance. The caveat is that this would require a refocusing of domestic production capacity to commodity lines that overlap those of the trading partners, especially those of the OECD nations, so as to be able to garner the benefits derivable from liberal trade policy.
\end{abstract}

Key words: Trade Liberalization, Economic Growth, West Africa, VECM

\section{Introduction}

Trade policy reforms and specifically trade liberalization has been a regular feature of West African economies since the mid-1980's when the World Bank/International Monetary Fund's designed structural adjustment programme was introduced. The general belief was that trade reforms, especially when combined with exchange rate reforms and better domestic macroeconomic policies could enhance trade induced economic expansion and consequently reverse the downward trend of African economies (Ekpo 2005; Yahya, Dantata and Mohammed 2013). Before this time, particularly between the early 1960s and the early 1980s, many African countries operated protectionist and highly interventionist trade regimes on both import and export sides. From the import side, trade regime was characterized by restrictive import licensing systems, and tight foreign exchange controls. On the export side, substantial implicit and explicit taxes, as well as prohibitions of certain export items and other non-tariff barriers, were common features of trade regimes.

Although opinions differ on trade liberalization-growth debate, international lending agencies such as the World Bank and the International Monetary Fund (IMF) make trade policy reform a major condition for granting aid and other kinds of external economic assistance to developing African countries. Liberal trade policy is also part of contemporary globalization policies pursued by both the developed and developing countries to promote world economic integration. While there is consensus on the need to implement economic reforms in Africa, there are doubts as to whether the region's exports and overall economic development would be enhanced by the adoption of programmes that involve more open economic policies. A positive nexus between trade liberalization and economic has been found for some developing countries and regions in Africa (see Balasssa 1985; Ram 1985, 1987; Bhagwati 1988; Greenaway and Nam 1988; Alam 1991; Salvatore and Hatcher 1992). Other studies conclude that trade liberalization does not lead to economic growth during period of decrease in world demand, and that some basic level of income is necessary for lower-income countries to benefit from outward oriented policies that may lead to growth (Olugbenga and Olowole 1998; Michaely 1977; Tyler 1981; Feder 1983; Helleiner 1986; Singer and Gray 1988 and Odedekun 1991). Admittedly, in GATT negotiated tariff reduction for instance, only to the extent that LDCs' exports to OECD countries overlap the commodities exchanged by the developed countries themselves would any benefits flow to the LDCs from the GATT tariff cuts. As we see in Ekong and Onye (2012a), if exports of developing countries are dissimilar,i.e., subject to little or no 'commodity overlap' then there will be little scope for trade diversion which would imply limited capacity of developing African countries to harness the benefits accruable from liberal trade policies.

As its contribution to literature, this paper examines the effects of trade policies (trade orientations), exports and investment growth on economic growth performance of West African (WA) economies over 19702011. Unlike the previous studies, we examine this issue within the context of a vector error correction model (VECM). A unique advantage of the VECM is that it treats each variable in the system as potentially endogenous and relates each variable to its own past values and to past values of all other variables (Sims 1980;Olugbenga and Oluwole1998). In addition, the VECM facilitates the dynamic analysis of the interactions among the variables.

The rest of this paper is organized as follows. Section 2 presents brief theoretical and empirical discourses, and some shortcomings of previous studies in this area. Section 3 dwells on the methodology employed. The data and estimated results are discussed in Section 4. The paper is concluded in section 5. 


\section{A Brief Theoretical and Empirical Discourse}

As we see in Olugbenga and Oluwole (1998), most previous investigations of the exports-growth linkage in developing countries employed the augmented production function of the type formulated by Balassa (1978) and Feder (1983). In the augmented production function, real output is specified as a function of capital and labor, and other macroeconomic variables such as exports and industrial production. A positive correlation between export growth and real output growth is then taken as an indication of the contributions of export-oriented policies to economic growth. Studies by Little et al. (1970), Michalopoulos and Jay (1973), Krueger (1978), Feder (1983), Kavoussi (1984), Balassa (1985), Ram (1987), and Singer and Gray (1988), among others, used variants of this output growth specification for various developing countries and regions. They concluded that export growth promotes economic growth. Inferences based on the regression from the augmented production function have been challenged by a number of studies. First, Bhagwati (1988) argued that the results of the regressions do not answer the question of whether or not the export promotion (EP) strategy is growth inducing. According to Bhagwati (1988) it is necessary to identify whether the superior export growth rates or higher export magnitudes belong to the EP countries. Second, Sheehey (1993) argued that the regression used in most of these studies involves a built-in correlation because exports are a component of GDP. To correct for the shortcomings inherent in these studies, some recent studies have used an index of trade orientation (trade policy variables)because it provides for a comprehensive determination of the impact of trade policy regimes on output growth in developing countries (see Moon 1997; Olugbenga and Oluwole 1998). Basically, the index combines several qualitative and quantitative indicators. These indicators take into consideration the effective rates of protection, reliance on direct import controls, use of export incentives, and the degree of exchange rate overvaluation. More importantly, the indicators enable countries to be classified into one of four classes of trade orientation: strongly outward-oriented, moderately outward-oriented, moderately inward-oriented, and strongly inward-oriented(see Moon 1997 for an exposition and country-classification). In their study, Salvatore and Hatcher (1992) used these classifications to evaluate the economic performance of 26 countries. They found partial support for the hypothesis that outward orientation leads to more efficient use of resources and growth. The problem with some of the more recent and previous studies in this area is that their conclusions are based on non-stationary data. It is quite clear from the empirical literature that the application of conventional econometric techniques to non-stationary (integrated) time series can give rise to misleading results and erroneous inferences (Sims et al.1990).

This study employs country-specific analysis as cross-country regressions are misleading since they do not reveal country-specific characteristics. Models that use cross-country data in this area are based on the implicit assumption that developing counties share common characteristics: low per capita income, reliance on imported technology and capital goods and the fact that these economies are largely agrarian, among others. While this may be true to a certain degree, the enormous diversity among WA economies in terms of economic, institutional, political and financial structures suggests that they differ in their exposure to economic problems and in their stabilization experiences. Most importantly, the developing countries differ in their reactions to economic shocks (Ekong and Onye, 2012b). Thus, the differences among WA countries suggest the importance and need for country-specific analysis over cross-country analysis. This is particularly important to ensure that country-specific economic policies are properly focused.

\section{Methodology}

The methodology adopted for this study follows the augmented production function due to Balassa (1978), Feder (1983), Ram (1987) and more recently, Olugbenga and Oluwole 1998. As a country-specific analysis, we focus on the interactions among these variables in individual countries. In fellowship with Olugbenga and Oluwole 1998, we expand upon the growth equation by including trade policy variables to capture the effects of trade orientations. The presence of both exports and trade policy variables in the same regression provides us with a useful reference for discussing the causal impacts of export earnings and trade orientations on real output growth rates.

For this study, the real output growth equation is expressed as:

$\mathrm{Y}=\alpha_{0}+\alpha_{1} \mathrm{EG}+\alpha_{2} \mathrm{TP}+\alpha_{3} \mathrm{~K}+\epsilon-$

(Where $\mathrm{Y}$ is real output defined as real gross domestic product per capita; EG is real exports measured as the ratio of merchandise exports to real GDP; $\mathrm{K}$ is investment rate measured as the ratio of gross domestic investment to GDP; and TPis the world Bank's index of trade orientation/policy dummy).

Based on the World Bank (various years) index of trade orientation, we compute a series of trichotomous trade policy $(T P)$ dummy variables to represent the trade policy regimes. We let $T P=1$ for strongly and moderately outward orientation, $T P=0$ for moderately inward orientation, and $T P=-1$ for strongly inward orientation (Olugbenga and Oluwole 1998; Moon 1997). This allows us to evaluate the separate impact of trade orientations on growth rates. The VECM is on annual time series for 1970-2011 for 12 WA economies for 
which information on trade orientation is provided from the World Bank study (see table 1 for the list of countries).

To ensure proper model specification and to reduce the possibility of arriving at spurious regression results, we examine the time series properties of the data using the Augmented Dickey Fuller test for a unit root and conduct a model diagnostic test for a long-run equilibrium relationship among our variables by employing Johansen and Juselius(1990) Maximum Likelihood test for cointegration. An augmented Dickey-Fuller (ADF) test for unit roots revealed that all of the log-level variables are integrated I (1), or are non-stationary but become integrated after first differencing. It has long been recognised that failure to account for cointegration would cause misspecification if the variables are cointegrated, and this might undermine the validity of the parameter estimates (Engle and Granger, 1987). The Johansen and Juselius (1990) maximum likelihood test procedure is preferred because it identifies the number of cointegrating vectors between the non-stationary level variables in the context of a vector error-correction model (VECM). The VECM is basically a vector autoregression (VAR) model in error correction form. In a system with two or more variables, a VECM, like the VAR model, treats each variable as potentially endogenous and relates the change in one variable to past equilibrium errors and to past changes in all variables in the system. The error correction (EC) term is the residual lagged one period derived from the estimated long-term cointegration relationship in equation (1).

The VECM is, thus, specified as follows

$\Delta \mathrm{Y}_{\mathrm{t}}=\beta_{0}+\sum_{i=1}^{m} \beta \mathrm{i} \Delta \mathrm{Y}_{\mathrm{t}-\mathrm{i}}+\sum_{i=1}^{n} \pi \mathrm{i} \Delta \mathrm{EP}_{\mathrm{t}-\mathrm{i}}+\sum_{i=1}^{p} \Psi \mathrm{i} \Delta \mathrm{K}_{\mathrm{t}-\mathrm{i}}+\mho \mathrm{TP}+\Theta \mathrm{EC}_{\mathrm{t}-1}+\mathrm{u}_{\mathrm{t}} \ldots--_{-(2)}$

The variables are as earlier defined in equation 1 .

\section{Data And Estimated Results}

The data used for this study are sourced from World Bank's World Development Indicators and Global Development Finance, and IMF's International Financial Statistics (IFS). All variables, except trade orientation, are used in their $\log$ form to correct for possible non-linearity. Table 1 reports the Eigen values and the likelihood ratio statistics which help us to determine the number of cointegrating vectors $(\mathrm{k})$ using the JohansenJuselius (1990) maximum likelihood approach. The null hypothesis of no cointegration $(\mathrm{k}=0)$ are tested against the alternative of $\mathrm{k}=1, \mathrm{k}=2, \mathrm{k}=3$, etc. Table 1 show that the null hypothesis of no cointegration $(\mathrm{k}=0)$ is rejected at the 5\% significance level. Since the likehood ratio statistics for $\mathrm{k}=1$ are all greater than the 5\% critical value for all countries except Liberia and Nigeria, the hypothesis that there is at least onecointegrating relation are also rejected. Overall, the results show that there may be up to three cointegrating vectors among the variables for most WA economies. This is further reinforced by the sharp fall in the Eigen value statistic for $\mathrm{k} \leftarrow 3$ (for most WA economies) which suggests that it is not necessary to search for a third vector between the series(Olugbenga and Oluwole 1998). We accept $\mathrm{k}=2$ which lead us to conclude that real output, export, investment growth and trade policies in each economy has at least two cointegrating vectors. Having determined the optimal lags in the VECM, the resulting equations are estimated as a joint system.

Because the usefulness of VECM for policy analysis is conditional on their lag structure, we statistically determine the optimal lag order on each variable by minimizing Akike's Final Prediction Error (FPE) (Akaike, 1969) following Hsiao (1987) and Olugbenga and Oluwole (1998). In the passing, one way to evaluate the coefficient estimates of the VECM is to examine the short run dynamics among the variables through the signs on the estimated lagged coefficients. This study makes use of an additional technique, namely, the variance decomposition which allocates the forecast error variance associated with each variable into that proportion attributable to its own innovations (residuals) and other innovations in all other variables in the VECM. Table 2 presents the coefficient estimates of equation 2 together with some summary statistics. To simplify the economic explanation of the short-run dynamics in the VECM, we sum the lagged coefficients of each variable and test for joint significance at $5 \%$ level.

Given the result in table 2, we use Nigeria for the purpose of illustration. The result for Nigeria show that the short-run dynamics of real output growth are best captured by a model which includes the first and second lags of exports (EP), but we report all of the lag coefficients under the single line $\sum \mathbf{E P}$. The diagnostic statistics show that the models explain relatively large proportions of the variations in economic growth across WA economies. The adjusted $\mathrm{R}^{2}$ values ran from $40 \%$ in Cote d'Ivoire (CIV)to $70 \%$ in Mali. The $\mathbf{R}^{2}$ values, coupled with the small values of standard errors, suggest that the models fit the data quite well and could be utilized for policy analysis. Given the satisfactory performance of the error correction models, we turn to a discussion of the estimated coefficients. The coefficients of the error correction terms $\left(\mathrm{EC}_{\mathrm{t}-1}\right)$ have negative signs as expected, but more importantly, they are statistically significant at the conventional level. This implies that real output adjusts to long-run equilibrium as represented by the structure of the cointegration regression specified in equation 1. 
Table 1 Cointegration Result (Johansen Maximum Likelihood Test)

\begin{tabular}{|c|c|c|c|c|c|c|}
\hline \multicolumn{7}{|c|}{ Cointegration LR test based on the Maximum Eigen values of the stochastic matrix, Y, EP, K. TP } \\
\hline Country & $\begin{array}{l}\text { Eigen } \\
\text { Value }\end{array}$ & Null & Alternative & $\begin{array}{l}\text { Likelihood ratio } \\
\text { statistic }\end{array}$ & $\begin{array}{l}5 \% \text { critical } \\
\text { value }\end{array}$ & $\begin{array}{l}1 \% \text { critical } \\
\text { value }\end{array}$ \\
\hline Benin & $\begin{array}{l}0.26 \\
0.34 \\
0.34 \\
0.12\end{array}$ & $\begin{array}{l}\mathrm{K}=0 \\
\mathrm{k} \leftarrow 1 \\
\mathrm{k} \leftarrow 2 \\
\mathrm{k} \leftarrow 3\end{array}$ & $\begin{array}{l}\mathrm{K}=0 \\
\mathrm{~K}=1 \\
\mathrm{~K}=2 \\
\mathrm{~K}=3\end{array}$ & $\begin{array}{l}61.2 * \\
39.2 * \\
18.5 * * \\
2.97\end{array}$ & $\begin{array}{l}55.32 \\
37.5 \\
16.35 \\
4.45\end{array}$ & $\begin{array}{l}59.23 \\
39.25 \\
20.5 \\
5.96\end{array}$ \\
\hline Burk. Faso & $\begin{array}{l}0.68 \\
0.24 \\
0.56 \\
0.15\end{array}$ & $\begin{array}{l}\mathrm{K}=0 \\
\mathrm{k} \leftarrow 1 \\
\mathrm{k} \leftarrow 2 \\
\mathrm{k} \leftarrow 3\end{array}$ & $\begin{array}{l}\mathrm{K}=0 \\
\mathrm{~K}=1 \\
\mathrm{~K}=2 \\
\mathrm{~K}=3\end{array}$ & $\begin{array}{l}98.5 * \\
70.4^{*} \\
62.78^{*} \\
1.45\end{array}$ & $\begin{array}{l}64.8 \\
54.2 \\
43.12 \\
3.02 \\
\end{array}$ & $\begin{array}{l}68.9 \\
67.1 \\
58.0 \\
5.32 \\
\end{array}$ \\
\hline Cape Verde & $\begin{array}{l}0.98 \\
0.29 \\
0.51 \\
0.16\end{array}$ & $\begin{array}{l}\mathrm{K}=0 \\
\mathrm{k} \leftarrow 1 \\
\mathrm{k} \leftarrow 2 \\
\mathrm{k} \leftarrow 3\end{array}$ & $\begin{array}{l}\mathrm{K}=0 \\
\mathrm{~K}=1 \\
\mathrm{~K}=2 \\
\mathrm{~K}=3\end{array}$ & $\begin{array}{l}68.7 * \\
46.34 * \\
30.36 * * \\
19.45\end{array}$ & $\begin{array}{l}53.12 \\
38.23 \\
27.53 \\
23.6\end{array}$ & $\begin{array}{l}66.34 \\
43.32 \\
40.53 \\
28.64\end{array}$ \\
\hline Cote d'Ivoire & $\begin{array}{l}0.77 \\
0.87 \\
0.44 \\
0.11\end{array}$ & $\begin{array}{l}\mathrm{K}=0 \\
\mathrm{k} \leftarrow 1 \\
\mathrm{k} \leftarrow 2 \\
\mathrm{k} \leftarrow 3\end{array}$ & $\begin{array}{l}\mathrm{K}=0 \\
\mathrm{~K}=1 \\
\mathrm{~K}=2 \\
\mathrm{~K}=3\end{array}$ & $\begin{array}{l}78.9 * \\
66.89 * * \\
30.54 \\
21\end{array}$ & $\begin{array}{l}60.4 \\
59.43 \\
43.7 \\
34.5\end{array}$ & $\begin{array}{l}72.45 \\
67.6 \\
45.76 \\
37.98\end{array}$ \\
\hline Gambia & $\begin{array}{l}0.82 \\
0.67 \\
0.49 \\
0.19 \\
\end{array}$ & $\begin{array}{l}\mathrm{K}=0 \\
\mathrm{k} \leftarrow 1 \\
\mathrm{k} \leftarrow 2 \\
\mathrm{k} \leftarrow 3\end{array}$ & $\begin{array}{l}\mathrm{K}=0 \\
\mathrm{~K}=1 \\
\mathrm{~K}=2 \\
\mathrm{~K}=3\end{array}$ & $\begin{array}{l}67.2^{*} \\
37.2^{*} \\
19.5^{* *} \\
3.97\end{array}$ & $\begin{array}{l}46.54 \\
36.67 \\
16.76 \\
4.87 \\
\end{array}$ & $\begin{array}{l}56.28 \\
45.45 \\
20.96 \\
5.98 \\
\end{array}$ \\
\hline Guinea & $\begin{array}{l}0.72 \\
0.56 \\
0.73 \\
0.04\end{array}$ & $\begin{array}{l}\mathrm{K}=0 \\
\mathrm{k} \leftarrow 1 \\
\mathrm{k} \leftarrow 2 \\
\mathrm{k} \leftarrow 3\end{array}$ & $\begin{array}{l}\mathrm{K}=0 \\
\mathrm{~K}=1 \\
\mathrm{~K}=2 \\
\mathrm{~K}=3\end{array}$ & $\begin{array}{l}61.2 * \\
39.2 * \\
18.5 * * \\
2.97\end{array}$ & $\begin{array}{l}56.89 \\
32.76 \\
16.7 \\
3.45\end{array}$ & $\begin{array}{l}59.34 \\
38.12 \\
27.98 \\
8.48\end{array}$ \\
\hline Guinea Bissau & $\begin{array}{l}0.83 \\
0.59 \\
0.82 \\
0.52\end{array}$ & $\begin{array}{l}\mathrm{K}=0 \\
\mathrm{k} \leftarrow 1 \\
\mathrm{k} \leftarrow 2 \\
\mathrm{k} \leftarrow 3\end{array}$ & $\begin{array}{l}\mathrm{K}=0 \\
\mathrm{~K}=1 \\
\mathrm{~K}=2 \\
\mathrm{~K}=3\end{array}$ & $\begin{array}{l}78.9 * \\
66.89 * * \\
30.54 \\
21\end{array}$ & $\begin{array}{l}56.7 \\
46.8 \\
40.6 \\
25 \\
\end{array}$ & $\begin{array}{l}60.45 \\
67.98 \\
50.97 \\
29\end{array}$ \\
\hline Mali & $\begin{array}{l}0.73 \\
0.86 \\
0.49 \\
0.00\end{array}$ & $\begin{array}{l}\mathrm{K}=0 \\
\mathrm{k} \leftarrow 1 \\
\mathrm{k} \leftarrow 2 \\
\mathrm{k} \leftarrow 3\end{array}$ & $\begin{array}{l}\mathrm{K}=0 \\
\mathrm{~K}=1 \\
\mathrm{~K}=2 \\
\mathrm{~K}=3\end{array}$ & $\begin{array}{l}68.7 * \\
46.34 * \\
30.36 * * \\
19.45\end{array}$ & $\begin{array}{l}53.12 \\
38.23 \\
27.53 \\
23.6\end{array}$ & $\begin{array}{l}67.34 \\
39.87 \\
31.28 \\
24.98\end{array}$ \\
\hline Niger & $\begin{array}{l}0.73 \\
0.86 \\
0.12 \\
0.43 \\
\end{array}$ & $\begin{array}{l}\mathrm{K}=0 \\
\mathrm{k} \leftarrow 1 \\
\mathrm{k} \leftarrow 2 \\
\mathrm{k} \leftarrow 3\end{array}$ & $\begin{array}{l}\mathrm{K}=0 \\
\mathrm{~K}=1 \\
\mathrm{~K}=2 \\
\mathrm{~K}=3\end{array}$ & $\begin{array}{l}69.7 * \\
47.34 * \\
23.4 \\
13.87\end{array}$ & $\begin{array}{l}66.98 \\
44.87 \\
24.65 \\
15.76 \\
\end{array}$ & $\begin{array}{l}68.97 \\
46.98 \\
34.87 \\
17.97 \\
\end{array}$ \\
\hline Nigeria & $\begin{array}{l}0.82 \\
0.26 \\
0.78 \\
0.23\end{array}$ & $\begin{array}{l}\mathrm{K}=0 \\
\mathrm{k} \leftarrow 1 \\
\mathrm{k} \leftarrow 2 \\
\mathrm{k} \leftarrow 3\end{array}$ & $\begin{array}{l}\mathrm{K}=0 \\
\mathrm{~K}=1 \\
\mathrm{~K}=2 \\
\mathrm{~K}=3\end{array}$ & $\begin{array}{l}87.98 * \\
51.2 \\
34.12 \\
13.67\end{array}$ & $\begin{array}{l}76.98 \\
60.34 \\
40.65 \\
20.89\end{array}$ & $\begin{array}{l}80.65 \\
63.78 \\
53.87 \\
26.87\end{array}$ \\
\hline Senegal & $\begin{array}{l}0.67 \\
0.87 \\
0.23 \\
0.10\end{array}$ & $\begin{array}{l}\mathrm{K}=0 \\
\mathrm{k} \leftarrow 1 \\
\mathrm{k} \leftarrow 2 \\
\mathrm{k} \leftarrow 3\end{array}$ & $\begin{array}{l}\mathrm{K}=0 \\
\mathrm{~K}=1 \\
\mathrm{~K}=2 \\
\mathrm{~K}=3\end{array}$ & $\begin{array}{l}98.45 * \\
87.56 * \\
61.25 * * \\
37.23\end{array}$ & $\begin{array}{l}60.87 \\
58.97 \\
52.67 \\
38.79\end{array}$ & $\begin{array}{l}69.78 \\
67.86 \\
63.76 \\
42.50\end{array}$ \\
\hline Liberia & $\begin{array}{l}0.49 \\
0.91 \\
0.98 \\
0.12\end{array}$ & $\begin{array}{l}\mathrm{K}=0 \\
\mathrm{k} \leftarrow 1 \\
\mathrm{k} \leftarrow 2 \\
\mathrm{k} \leftarrow 3\end{array}$ & $\begin{array}{l}\mathrm{K}=0 \\
\mathrm{~K}=1 \\
\mathrm{~K}=2 \\
\mathrm{~K}=3\end{array}$ & $\begin{array}{l}\text { 76.98* } \\
\text { 55.78 } \\
40.34 \\
3.87\end{array}$ & $\begin{array}{l}67.59 \\
58.9 \\
47.98 \\
5.85\end{array}$ & $\begin{array}{l}71.94 \\
61.45 \\
51.78 \\
6.87\end{array}$ \\
\hline
\end{tabular}

Note: $*$ and $* *$ indicates significance at the $1 \%$ and $5 \%$ level, respectively. 
The Growth Implication Of Trade Liberalization In West Africa

Table 2: Estimate of Error Correction Output Growth Models for 12 WA Economies

\begin{tabular}{|c|c|c|c|c|c|c|c|c|c|c|c|c|}
\hline \multicolumn{13}{|c|}{ COUNTRY } \\
\hline Exp. Var & $\overline{\text { BENIN }}$ & BFA & $\mathrm{CPV}$ & $\overline{\mathrm{CIV}}$ & $\overline{\text { GAM }}$ & GUN & GUB & MALI & NIGR & NIGA & SEN & $\begin{array}{ll}\text { LIB } \\
\end{array}$ \\
\hline $\mathrm{EC}_{\mathrm{t}-1}$ & $\begin{array}{l}-0.1 \\
(-4.31)\end{array}$ & $\begin{array}{l}-0.1 \\
(- \\
3.49)\end{array}$ & $\begin{array}{l}-0.21 \\
(-3.7)\end{array}$ & $\begin{array}{l}-0 \\
(- \\
2.4)\end{array}$ & $\begin{array}{l}-0.1 \\
(-2.21)\end{array}$ & $\begin{array}{l}-0 \\
(- \\
3.21)\end{array}$ & $\begin{array}{l}-0 \\
(-1.9)\end{array}$ & $\begin{array}{l}-0.5 \\
(- \\
2.471)\end{array}$ & $\begin{array}{l}-0 \\
(-0.49)\end{array}$ & $\begin{array}{l}-0.9 \\
(-2.6)\end{array}$ & $\begin{array}{l}-0.1 \\
(-3.56)\end{array}$ & $\begin{array}{l}-0.45 \\
(-4.12)\end{array}$ \\
\hline$\sum \mathrm{Y}$ & $\begin{array}{l}-0.4 \\
-1.79\end{array}$ & $\begin{array}{l}0.2 \\
2.2\end{array}$ & $\begin{array}{l}1.01 \\
5.52\end{array}$ & $\begin{array}{l}0.6 \\
2.22\end{array}$ & $\begin{array}{l}0.87 \\
8.7\end{array}$ & $\begin{array}{l}0.6 \\
(2.5)\end{array}$ & $\begin{array}{l}1 \\
4.9\end{array}$ & $\begin{array}{l}0.6 \\
(5.5)\end{array}$ & $\begin{array}{l}0.728 \\
(2.92)\end{array}$ & $\begin{array}{l}0.38 \\
(4.6)\end{array}$ & $\begin{array}{l}0.06 \\
(0.567)\end{array}$ & $\begin{array}{l}1.033 \\
(5)\end{array}$ \\
\hline$\sum \mathrm{K}$ & $\begin{array}{l}0.2 \\
(2.422)\end{array}$ & $\begin{array}{l}-0.2 \\
(-2.2)\end{array}$ & $\begin{array}{l}-0.35 \\
(-2.2)\end{array}$ & $\begin{array}{l}0.18 \\
2.4\end{array}$ & $\begin{array}{l}-0.1 \\
(- \\
1.004)\end{array}$ & $\begin{array}{l}-0 \\
(-1.4)\end{array}$ & $\begin{array}{l}0.1 \\
1\end{array}$ & $\begin{array}{l}-0.6 \\
(-2.9)\end{array}$ & $\begin{array}{l}0.047 \\
0.44\end{array}$ & $\begin{array}{l}0.66 \\
1.1\end{array}$ & $\begin{array}{l}-0.1 \\
(-1.778)\end{array}$ & $\begin{array}{l}0.24 \\
(1.53)\end{array}$ \\
\hline$\sum \mathrm{EP}$ & $\begin{array}{l}0.04 \\
1.5\end{array}$ & $\begin{array}{l}-0.9 \\
(-7.5)\end{array}$ & $\begin{array}{l}0.44 \\
2.44 \\
\end{array}$ & $\begin{array}{l}0.11 \\
2.8\end{array}$ & $\begin{array}{l}0.06 \\
1.7\end{array}$ & $\begin{array}{l}0.3 \\
2.3\end{array}$ & $\begin{array}{l}0.3 \\
3.4\end{array}$ & $\begin{array}{l}-0.5 \\
-7\end{array}$ & $\begin{array}{l}0.169 \\
0.34\end{array}$ & $\begin{array}{l}0.2 \\
(3.5)\end{array}$ & $\begin{array}{l}0.67 \\
5\end{array}$ & $\begin{array}{l}0.667 \\
4.13\end{array}$ \\
\hline$\sum \mathrm{TP}$ & $\begin{array}{l}0.28 \\
1.78\end{array}$ & $\begin{array}{l}0.16 \\
2.4\end{array}$ & $\begin{array}{l}0.78 \\
5.3\end{array}$ & $\begin{array}{l}-0.1 \\
(- \\
3.4)\end{array}$ & $\begin{array}{l}-0.2 \\
(-1.34)\end{array}$ & $\begin{array}{l}0.5 \\
(3.3)\end{array}$ & $\begin{array}{l}0 \\
0.1\end{array}$ & $\begin{array}{l}-0.2 \\
(- \\
1.269)\end{array}$ & $\begin{array}{l}-0.323 \\
-1.29\end{array}$ & $\begin{array}{l}0.01 \\
0.3\end{array}$ & $\begin{array}{l}0.2 \\
(3.6)\end{array}$ & $\begin{array}{l}0.371 \\
(1.3)\end{array}$ \\
\hline $\begin{array}{l}\text { Statistics: } \\
\text { Adj. } R^{2} \\
\text { s.d. } \\
\sigma\end{array}$ & $\begin{array}{l}0.46 \\
0.12 \\
0.391\end{array}$ & $\begin{array}{l}0.6 \\
0.29 \\
0.19\end{array}$ & $\begin{array}{l}0.6 \\
0.64 \\
0.09\end{array}$ & $\begin{array}{l}0.40 \\
0.06 \\
0.06\end{array}$ & $\begin{array}{l}0.52 \\
0.34 \\
0.66\end{array}$ & $\begin{array}{l}0.41 \\
0.1 \\
0.23\end{array}$ & $\begin{array}{l}0.5 \\
0.2 \\
0.17\end{array}$ & $\begin{array}{l}0.67 \\
0.24 \\
0.1\end{array}$ & $\begin{array}{l}0.52 \\
0.112 \\
0.106\end{array}$ & $\begin{array}{l}0.45 \\
0.08 \\
0.06\end{array}$ & $\begin{array}{l}0.7 \\
0.22 \\
0.06\end{array}$ & $\begin{array}{l}0.452 \\
0.44 \\
0.14\end{array}$ \\
\hline
\end{tabular}

$\mathbf{R}^{2}$ is the coefficient of determination adjusted for degrees of freedom; $t$ statistics are reported in parenthesis; $\boldsymbol{\sigma}$ is the standard error of the equation;s.d. is the standard error of the dependent variable.

The coefficient of $\mathrm{Y}$ is positive and significant at the 5\% level for all of the countries, except for Benin and Senegal. For Benin, the parameter estimate of $\mathrm{Y}$ is negative and statistically insignificant. It is worth noting that our finding for $\mathrm{Y}$ is mixed but consistent with the results of previous and more recent models of this relationship. Whereas the coefficient of the investment growth $(\mathrm{K})$ variable is positive and significant in Benin, it is positive but statistically insignificant in Guinea Bissau (GUB), Niger (NIGR), Nigeria (NIGA) and Liberia (LIB). On the other, the coefficient of investment growth (K) is negative and significant at the 5\% in Burkina Faso (BFA), Cape Verde (CPV) and Mali. The positive association between investment rate and real output growth is consistent with the neoclassical growth theory. The mixed result shown by the relationship between economic growth and investment may be due to the reduction in investment as percentage of real GDP over the years in these countries. Furthermore, this may also be due to high level of subsidy and exchange rate benefits given to investors as governments attempt to artificially induce industrialization through import-substitution policies. For this study, the signs and the statistical significance of the coefficients on the export growth and trade policy variables are particularly important. Whereas the coefficients of the export growth are positive and statistically significant at the 5\% level and better in Cape Verde (CPV), Cote d'Ivoire (CIV), Guinea (GUN), Guinea Bissau (GUB), Senegal (SEN), Nigeria (NIG) and Liberia (LIB), they are insignificant in Benin (BEN), Gambia (GAM) and Niger (NIGR). The coefficients show the wrong signs in Burkina Faso and Mali. This particular result suggests that whereas export exerts positive and significant influence on economic growth in some WA countries, it has negative or no influence in others. This result is not surprising if one considers the fact that WA economies are largely dependent on the exports of a few primary commodities that have limited domestic markets, and import practically all of the capital goods and inputs used in the production process. The finding that exports exert significantly positive influence on growth suggests that export-led growth is a feasible strategy for WA countries. With regard to the trade policies dummies, we find significantly positive effects of trade orientations on economic growth for four countries- BFA, CPV, GUN and SEN.

Overall, the results suggest that the contribution of export expansion to economic growth is apparently independent of each country's trade orientation. Most importantly, our empirical results support the hypothesis that trade liberalization, which incorporates domestic policy reforms that reduce domestic controls and regulations, can lead to a more efficient utilization of resources and foster sustained economic growth in developing WA countries.

The results of the decompositions of the forecast-error variances are reported in Table 3. Since our primary focus is on changes in economic growth that are likely to result from shocks to trade policies, exports, and investment, we present only the variance decomposition for the real output growth equation for 12 forecast horizons (full result are available on request). By showing the contribution of each shock (from trade policy, export growth and investment) to growth in real output, the variance decomposition gives an indication of which shock is more predominant in accounting for the variability in real output across WA economies (see Ekong and Onye 2012b). As an illustration, let us take the example of Cote d'Ivoire and Liberia that consistently maintained a strong outward-orientation according to the World Bank. The results of the variance decompositions shows that trade policies provide significant predictive power for real output growth. Overall, 
the results of the variance decompositions show the relevance of the explanatory variables in explaining real output growth.

Table 3: Forecast Error Decomposition of Real Output Growth

\begin{tabular}{|c|c|c|c|c|c|c|}
\hline \multirow[b]{2}{*}{ country } & \multirow[b]{2}{*}{ variance of } & \multirow[b]{2}{*}{ Forecast horizon } & \multicolumn{4}{|c|}{$\%$ of forecast var. explained by shocks to : } \\
\hline & & & $\mathrm{y}$ & EP & $\mathrm{K}$ & TP \\
\hline \multirow[t]{3}{*}{ Benin } & $\mathrm{Y}$ & 4 & 83.88 & 56.21 & 0.67 & 9.23 \\
\hline & & 8 & 77.13 & 2.22 & 0.39 & 20.25 \\
\hline & & 12 & 74.85 & 51.29 & 0.34 & 23.5 \\
\hline \multirow[t]{3}{*}{ BFA } & $\mathrm{Y}$ & 4 & 84.63 & 6.11 & 2.5 & 6.76 \\
\hline & & 8 & 49.72 & 19.34 & 5.48 & 25.45 \\
\hline & & 12 & 36.42 & 24.67 & 4.83 & 34.09 \\
\hline \multirow[t]{3}{*}{$\mathrm{CPV}$} & $\mathrm{Y}$ & 4 & 64.43 & 81.07 & 18.39 & 16.12 \\
\hline & & 8 & 38.18 & 15.38 & 17.2 & 29.24 \\
\hline & & 12 & 40.16 & 10.69 & 22.44 & 26.72 \\
\hline \multirow[t]{3}{*}{ CIV } & $\mathrm{Y}$ & 4 & 13.01 & 30.51 & 12.59 & 43.89 \\
\hline & & 8 & 13.6 & 32.46 & 11.95 & 41.99 \\
\hline & & 12 & 14.17 & 32.47 & 11.83 & 41.53 \\
\hline \multirow[t]{3}{*}{ GAM } & Y & 4 & 62.61 & 70.1 & 27.54 & 9.75 \\
\hline & & 8 & 46.7 & 0.29 & 40.65 & 7.88 \\
\hline & & 12 & 39.93 & 0.65 & 47.21 & 4.71 \\
\hline \multirow[t]{3}{*}{ GUN } & $\mathrm{Y}$ & 4 & 18.19 & 24.84 & 20.06 & 13.71 \\
\hline & & 8 & 11.92 & 20.54 & 20.84 & 10.1 \\
\hline & & 12 & 12.16 & 19.96 & 21.44 & 4.78 \\
\hline \multirow[t]{3}{*}{ GUB } & Y & 4 & 49.37 & 1.96 & 48.04 & 2.55 \\
\hline & & 8 & 21.03 & 43.53 & 69.53 & 3.24 \\
\hline & & 12 & 11.98 & 3.22 & 73.93 & 1.41 \\
\hline \multirow[t]{3}{*}{ MALI } & $\mathrm{Y}$ & 4 & 85.84 & 50.48 & 12.88 & 7.88 \\
\hline & & 8 & 80.09 & 0.17 & 18.66 & 22.32 \\
\hline & & 12 & 78.29 & 30.11 & 20.92 & 3.26 \\
\hline \multirow[t]{3}{*}{ NIGR } & $\mathrm{Y}$ & 4 & 62.01 & 6.62 & 5.33 & 2.82 \\
\hline & & 8 & 60.04 & 7.53 & 5.08 & 2.82 \\
\hline & & 12 & 58.52 & 44.88 & 4.89 & 22.32 \\
\hline \multirow{3}{*}{ NIGERIA } & $\mathrm{Y}$ & 4 & 82.76 & 4.71 & 6.68 & 20.25 \\
\hline & & 8 & 71.92 & 13.71 & 10.26 & 23.5 \\
\hline & & 12 & 72.35 & 10.1 & 11.63 & 6.76 \\
\hline \multirow{3}{*}{ SEN } & Y & 4 & 76.44 & 4.78 & 17.59 & 25.45 \\
\hline & & 8 & 61 & 2.55 & 26.24 & 34.09 \\
\hline & & 12 & 58.96 & 3.24 & 22.32 & 5.48 \\
\hline \multirow[t]{3}{*}{ LIB } & Y & 4 & 72.55 & 1.41 & 83.26 & 4.83 \\
\hline & & 8 & 69.92 & 0.81 & 72.82 & 18.39 \\
\hline & & 12 & 69.61 & 0.56 & 52.82 & 17.2 \\
\hline
\end{tabular}

\section{Conclusions}

Most existing studies of the export-growth nexus in developing countries have employed the growth rate of exports as proxies for trade policy. Michaely (1977), Bhagwati (1988) and Sheehey (1993) as cited in Olugbenga and Oluwole (1998) have argued that this approach leaves the link between trade policies orientations (trade policies) on real economic and real output growth undetermined. Taking into consideration most of the problems associated with previous studies, we use a more direct measure of trade policy compiled by the World Bank (growth rates of real output, trade policy, and exports) to investigate the short-run dynamics and long-run relationships among trade orientations, growth rates of exports, investment, and real output growth in 12 WA countries over 1970-2011. Relying on variance decompositions within the framework of VECM, our results show that changes in exports and trade policies have positive and lasting impact in 8 of the $12 \mathrm{WA}$ economies. Although we focused on the effect of trade orientations (trade policies) on real output growth, our result are consistent with the export promotion hypothesis. The closed association among growth of real output, trade policy, export growth and investment suggest that it is possible to stimulate real output growth in WA through an outward -looking strategy of export expansion. The caveat is that this would require a refocusing of domestic production capacity to commodity lines that overlap those of the trading partners, especially those of the OECD nations, so as to be able to garner the benefits accruable from liberal trade reforms. This is particularly so because, if exports of developing countries are dissimilar,i.e., subject to little or no 'commodity overlap' with those of their major trading partners, then there will be little scope for 'trade diversion'. This would imply limited capacity of developing WA countries to harness the benefits accruable from trade liberalization. 


\section{References}

[1]. Akaike, H. (1969). Fitting Auto-Regressions for Prediction.Annals of the Institute of Statistical Mathematics, $21,243-247$.

[2]. Alam, S.M. (1991). Trade orientation and macroeconomic performance in LDCs: An empirical study. Economic Development and Cultural Change, 42, 839-848.

[3]. Balassa, B. (1978). Exports and Economic Growth: Further Evidence. Journal of Development Economics 5, $181-189$.

[4]. Balassa, B. (1985). Exports, Policy Choices, and Economic Growth in Developing Countries after the 1973 Oil Shock.Journal of Development Economics, 18,23-35.

[5]. Bhagwati, J. (1988). Export Promoting Trade Strategy: Issues and Evidence. World Bank Research Observer, 3, $27-58$.

[6]. Ekong, N. C., \&Onye, U. K. (2012a). Economic Development in Nigeria: The Basic Needs Approach. Journal of Economics and Sustainable Development, 3 (10), 54-65.

[7]. Ekong, N. C., \&Onye, U. K. (2012b). On the Feasibility on a Common Currency in West Africa: Evidence from a Multivariate Structural VAR Approach. Current Research Journal of Economic Theory, 4 (4), 120-131.

[8]. Ekpo, A. H.(2005). Fiscal Theory and Policy: Selected Essay. Printed by Somaprint Ltd, 2005.

[9]. Feder, G. (I983).On Exports and Economic Growth.Journal of Development Economics, 12,59-74. Bulletin of Economics and Statistics 52, 169-210.

[10]. Greenaway, D. and Nam, C. H. (1988). Industrialization and Macroeconomic Performance in Developing Countries under Alternative Trade Strategies. Kyklos, 41,419-435.

[11]. Helleiner, G. K. (1986). Outward orientation, import instability and African economic growth: an empirical investigation. In Theory and Reality in Development: Essays in Honor of Paul Steeton, ed. S. Lall and F. Stewart, pp. 139-153. Macmillan, London.

[12]. Hsiao, M. C. W. (1987). Tests of Causality and Exogeneity between Exports and Economic Growth: The case of the Asian NIC's. Journal of Economic Development, 12, 143-159.

[13]. International Monetary Fund (various years a).International Financial Statistics Yearbook.International Monetary Fund, Washington, DC.

[14]. International Monetary Fund (various years b) World Economic Outlook: A Survey by the Staff of the International Monetary Fund. International Monetary Fund, Washington, DC.

[15]. Johansen, S. and Juselius, K. (1990) Maximum likeliestimation.and testing. Econometrica 55, 251-276.

[16]. Kavoussi, R. M. (1984). Export Expansion and Economic Growth: Further Empirical Evidence. Journal of Development Economics, 14, $241-250$.

[17]. Krueger, A. 0.(1980). Trade Policv as an Input to Development. AmericanEconomic Review Papers and Proceedings, 70, 288292.

[18]. Krueger, A. 0. (1978). Foreign Trade Regimes and Economic Development: Liberalization Attempts and Consequences. Ballinger, Cambridge, MA.For National Bureau of Economic Research, New York.

[19]. Little I., Scitovsky T. and Scott, M. (1970).Industry and Trade in Some Developing Countries. London: Oxford University Press.

[20]. Michaely, M. (1977). Exports and growth: an empirical investigation. Journal of Development Economics, 4, 49-53.

[21]. Michalopoulos, C. and Jay, K. (1973) Growth of Exports and Income in the Developing World: A Neoclassical View. Discussion Paper No. 28, Agency for International Development, Washington, DC.

[22]. Moon, E. B. (1997).Exports, Outward-oriented Development, and Economic Growth, OOD.205, Lehigh University Bethlehem, PA 18015 .

[23]. Odedokun, M. 0. (1991). Differential impacts of export expansion on economic growth in the LDCs: a comparison of evidences across regional and income groups and between the decades of 1970s and 1980s. East African Economic Review 7,69-93.

[24]. Olugbenga, O. A., \&Oluwole, O. (1998). Can Trade Liberalization Stimulate Economic Growth in Africa? World Development, 26 (3), 497-506.

[25]. Ram, R. (1985). Exports and economic growth: some additional evidence. Economic Development and Cultural Change, 33,415425 .

[26]. Ram, R. (1987). Exports and economic growth in developing countries: evidence from time series and cross-section data. Economic Development and Cultural Change, 36, 51-72.

[27]. Salvatore, D. and Hatcher, T. (1992).Inward oriented and outward oriented trade strategies.Journal of Development Studies, 27, 725 .

[28]. Sheehey, E. J. (1993). Exports as a factor of production: a consistency test. World Development, 21, 155-160.

[29]. Sims, C. A. (1980). Macroeconomics and Reality.Econometrica,48,1-46.

[30]. Sims, C. A., James, H. and Watson, M. W. (1990). Inference in linear time series models with some unit roots. Econometrica, 58, 113-144.

[31]. Singer, H. W. and Gray, P. (1988). Trade policy and growth of developing countries: some new data. World Development, 16, 395403.

[32]. Tyler, W. G. (1981) Growth and export expansion in developing countries: some empirical evidence. Journal of Development Economics, 9, 121-130.

[33]. World Bank (various years a) World Development Report.World Bank, Washington, DC.

[34]. World Bank (various years b) World Tables. John Hopkins University Press, Baltimore.

[35]. Yahya, A. Z., Dantata, U. Y., \&Abdullahi, M. (2013). Relationship between Trade Liberalization and Economic Growth: Empirical Evidence from Sub-Sahara Africa. African Journal of Social Sciences, 3 (1), 111-120. 